\title{
'What happens after saying no?' Egyptian Uprisings and Afterwords in Basma Abdel Aziz's The Queue (2016) and Omar Robert Hamilton's The City Always Wins (2017)
}

\begin{abstract}
This article compares two creative continuations to the 2011-13 Egyptian uprisings: Basma Abdel Aziz's dystopian novel The Queue (2016; al-Tābour, 2013) and Omar Robert Hamilton's semi-autobiographical fiction The City Always Wins (2017). These two novels, written in the bitter aftermath of Egypt's spectacular twenty-first century revolts, share a morbid tonality and concomitantly sceptical outlook toward representation, despite their different generic affiliations. They nevertheless both gamble on the performative potential of creative fiction. In the context of an ostensibly failed revolution, we need to ask what kinds of reader response are evoked by literary diagnoses of the present that flirt with alexithymia (the inability to describe feeling); in other words, how a counterfuturistic afterwardly aspires to be productive. I argue that these two novels, as afterwords on a revolution, animate a tensile present that sediments a century of thwarted popular aspirations, enfolds critical temporalities, and, in the case of both novels, just resists closure. The article uses the concepts of achrony and 'robbed time' to define the afterwardly as creative, counter-textual provocation skirmishes that continually reterritorialize the political and material ground.
\end{abstract}

\section{Article}

This article compares two creative continuations to the 2011-13 Egyptian uprisings. Basma Abdel Aziz's The Queue (2016), originally published as al-Tābour (2013), exemplifies a new wave of speculative Egyptian fiction, reconfiguring its author's diagnosis of contemporary reality as 'a badly written dystopia' (Abdel Aziz 2017). Omar Robert Hamilton's The City Always Wins (2017) augments a testimonial genre that proliferated during the uprisings 
themselves. These two novels, written in the bitter aftermath of Egypt's spectacular twentyfirst century revolts, share a morbid tonality and concomitantly sceptical outlook toward representation, despite their different generic affiliations. They nevertheless gamble on the performative potential of creative fiction. As 'afterwords' on a revolution, The Queue and The City Always Wins animate a tensile present that sediments a century of thwarted popular aspirations, enfolds critical temporalities, and - just - resists closure.

The editors of CounterText propose the countertextual as 'revanchism' or reterritorialisation of the literary, a 'retur[n] upon culture in affirmation of [literature's] achronic rather than anachronous qualities' (Callus and Corby 2015: v). I am reminded of the repurposing, by Algerian writer Assia Djebar, of the rebato, a series of 'rapid offensives alternating with as swift retreats' (1985: 215) that produces a layered space conjoining competing forces (Erickson, 2009: 50). For the narrator of Fantasia: An Algerian Cavalcade (L'Amour, la fantasia, 1985), the French colonial legacy is subjectively reterritorialised by Algerian Arabic and Amazigh: 'the French tongue, with its body and voice, has established a proud presidio within me, while the mother-tongue, all oral tradition, all rags and tatters, resists and attacks between two breathing spaces' (Djebar 1985: 215). This skirmishing is intimately embodied, the relation between breath/voice and language(s) conceived in relation to "the rhythm of the “rebato" beating in me' ('le rythme du "rebato" en moi s'éperonnant') (Djebar 1995: 299). ${ }^{1}$ Djebar illustrates ways in which a colonial epoch generates 'anachronic "postcolonial" impulses' (West-Pavlov, 2013: 162). We might also connect the rebato to the homonymous musical term tempo rubato, 'robbed time', a discretionary adjustment of tempo indicative of a creative practitioner's expressive freedom. That which is framed as 'feminine', indigenous, and resistant in the Djebar quotation above occurs in the space between breaths. This recalls syncopation (one meaning of the French contretemps), which accentuates non-standard beats. 
Djebar's writing invokes 'contretemps' as a quarrel or an unforeseen occurrence; it is derived from an attacking move (originally in fencing) 'made at an inopportune moment' (Concise OED 2006: n.p.). Her Fantasia models ways in which literature might 'interven[e] in a timely fashion, just at the pause, on the offbeat' of history - in countertime, countertextually (Rice 2006: 164, first emphasis mine). If deviation from an expected rhythm defamiliarises a pattern within a measure of time, achrony critically engages our chronometric time system itself (see West-Pavlov 2013: ch. 1). As opposed to anachrony, which presupposes a disavowed chronology, achrony challenges the progressive logic of linearity, hence received notions of historical teleology, living towards death, and - on the narrative plane - emplotment toward resolution, closure, and stasis (see Brooks 1984). Achronically speaking, there can be no discrete and stable 'afterwards' - a word which in itself suggests a predisposition rather than an achievement.

This recalls what is useful about invocations of an 'Arab Spring'. The term implies an impermanent state but an inevitably repeating inclination; it is legible as a counter-historical mode that anticipates its opposite: the repeated frustrating of popular counter-politics. As a range of commentators on twenty-first century Arab uprisings observe, a cycle of thwarted revolutionary beginnings, punctured by the 'morbid symptoms' of a moribund state that refuses yet to die, produces 'a fraught palimpsest, over [...] a brief but intense window of time' (Achcar 2016; Bugeja 2015: 7). This sense of temporal overlay - and the 'fraught process' of attempting to narrate it - illustrates that the 'Arab Spring' refuses to yield a 'precise beginning' or 'proximity towards any kind of ending'; its aftermath thus lends itself to speculative genres (Murphy 2017: n.p.). 
However, if achronic paradigms present as apt, a progressive agenda remains apparent. I chart elsewhere the longue durée of Egyptian ascension toward postcoloniality in literature of the last century (Moore 2018: ch. 1). We see, from at least Naguib Mahfouz's monumental Cairo Trilogy (1956-57) onwards, oscillation between popular struggle - al-thawrah as collective, unfinished revolt - and regime co-optation of revolutionary rhetoric (see also Brand 2014: ch. 3). Egyptian writers can be defined as the vanguard of democracy, insofar as their mission is 'receptivity and co-articulation' (Rooney 2011: 369). They dissent from regime construction of material reality (al-hayat al-mahsusa: see Bugeja 2015), including 'chronographies of power' in which lived time is differentially distributed according to the material (dis)investment of the state (Sharma 2014). Abdel Aziz and Hamilton contribute to this ongoing production of structurally prospective fictions, through the (different) ways they (to repeat Rooney's term above) 'co-articulate' a tensile present.

\section{Still Waiting: Basma Abdel Aziz's The Queue (2013/2016)}

Future-set 'speculative' genres, particularly (if somewhat tautologically) 'critical dystopias', are conspicuously burgeoning across the Arab world (Murphy 2017: n. p.). High-profile Egyptian examples include Ahmed Khaled Towfik's Utopia (2008/2011), Nael Eltoukhy’s Women of Karantina (2014; Nisa' al-Karantina, 2013), Mohammad Rabie's Otared (2016; 'Utarid, 2014), and Abdel Aziz's novel discussed here. ${ }^{2}$ The dystopian turn returns us, in fact, to pre-2011 literary trends. Anwar Sadat's infitah or 'open door' policies consolidated a pervasive post-1967 disillusionment with Egyptian nationalist, pan-Arab, and revolutionary narratives, a structure of feeling exacerbated by increased socio-economic disparity, neoliberalism, and securitisation in the Mubarak era (see Hafez 2010; Mehrez 2010). Egyptian writers have, particularly since the 1990 s, transmitted a social and political reality that is 
'mired, confusing, with unclear horizons' (Elsadda 2012: 155). This is often symptomatically presented through fractured narrations by alienated characters (dis)located in peripheral urban 'non-places' (Hafez 2010).

Whereas dystopian narratives generally 'reveal an aptitude to narrate in the conditional tense the genre's "what-ifness" - contemporary Egyptian dystopias tend to express 'what already is' (Murphy 2017: n. p.). Jussi Parikka, analysing contemporary Arab visual media, similarly identifies 'counterfuturisms' as 'productive disjunctive futurisms that investigate the conditions of existence of the contemporary moment' (2018: 41). Abdel Aziz's wry reference to Egypt's 'badly written' contemporary reality underlines what is at stake. It suggests less that things could get worse, than that life is already almost too terrible to imagine; its representation requires considerable literary skill. Egyptian dystopian fiction might more accurately be defined as dyschronotopic: the future collapses backward into a nightmarish present reality, rather than functioning as a cautionary horizon. We need to consider, however, whether specular (mirroring) time-space proximity, as opposed to speculative (conjectural) distanciation, imaginatively enables viable futures; to scrutinise what, if anything, is 'productive' about 'counterfuturistic' afterwords on the 2011-13 uprisings.

Abdel Aziz - journalist, sociologist, activist, trauma counsellor, and debut author of The Queue - accords a provocative remit to literature: she has stated her desire to encourage reader reaction in a post-uprising environment that shows signs of political exhaustion and in which censorship is resurgent (Abdel Aziz 2017: n. p.). ${ }^{3}$ The Quеuе hyperbolises Egypt's post-revolutionary present. In an interminable queue inspired by the author's real-life observation of unmoving lines of Egyptians outside a closed government building in Cairo (Lynx Qualey 2017: n. p.), the novel's denizens wait for the authorities - who manifest facelessly as 'the Gate' - to 
dispense documentary evidence of their existence. The novel opens with 'Document No. 1', introducing its protagonist by name (Yehya Gad el-Rab Saeed), age (38), marital status (single), place of residence (District 9 - Building 1), and occupation (sales representative). The plot, such as it is, involves Yehya's futile quest, aided by girlfriend Amani and friend Nagy, to gain permission from the Gate for surgery to remove a bullet in his gut. He requires, in fact, the authorities to recognise him as more than the sum of his officially documented parts. However, the bullet was acquired because Yehya participated in what are officially disavowed as 'Disgraceful Events' (Abdel Aziz 2017: 7 passim). In any case, the Gate never opens for anyone. Its function, by the time the novel opens, has become purely symbolic: it is less specific site - the converse of an opening that its name suggests - than metonymy of a system that both functionally interpellates and politically excludes every named character. Capillary power effectively regulates the social body. The Gate has 'insinuated itself into everything, [so that] people didn't know where its affairs ended and their own began' (Abdel Aziz 2016: 31).

Hermeneutical challenges are posed, to the reader of this novel, by the warp and weft of authoritative discourse enmeshing thoroughly subjectified characters. The Queue strategically reproduces an overall effect of dysphoria, sensory diminution, and blunted affect. Tonally, it tends toward the monochromatic, culminating in Amani's experience when she is caught and tortured. Amani's name means 'wishes', but in the empty 'nothingness' of the system's bowels, 'her dreams failed her, even her daydreams. First the colour drained from her imagination, then so did the light, so that her mind too became black' (Abdel Aziz 2016: 152). Political effects are throughout translated into psychological symptoms, rendering the individual responsible for his/her self-maintenance, or the price of failure thereof. Yehya's record indicates 'episodes of anxiety and irritability' and 'an irrational belief that he can alter reality' (102). He himself describes 'a silly little stomach pain' (15). Abdel Aziz turns the screw, albeit in the 
performative contradiction of a novel, by presenting her characters as alexithymic - they have almost no words for their radically diminishing capacity to feel. Yehya's name, a nearhomonym of the Arabic word for 'living', ironically signals a form of half or bare life from which the essentials - feeling and the ability to express it - are leached. A 'badly written' dystopian reality accrues meaning as one that threatens to exceed possible modes of expressing it.

Yehya's file is in the care of Dr Tarek Fahmy, whose thoughts bookend the narrative. This file threatens to prompt the medic's critical scrutiny even though, as delegate of a bio-political regime, he is by definition 'a man who didn't overstep boundaries [...] No questions, no problems - life passed him by both predictably and monotonously, just as he liked it' (Abdel Aziz 2016: 5). Tarek (whose name is also significant, as I will explain) does, however, tentatively sketch 'a figure resembling Yehya, nearly naked, and a small, solid circle, completely shaded in, occupying a space in the lower left part of his stomach' (25). He then erases it, so that when he lifts the paper up to the light, 'Yehya's outline and the shadow of the solid circle [are] no longer there' (26). Phrasing, however, suggests a ghostly imprint: a trace of Tarek's imperfect institutional alignment, as well as of Yehya's embodied history. But Yehya's file is also repeatedly modified by an unknown hand. At the end of the novel, Tarek observes that a sentence has been added that tersely monopolises the politics of representation, consolidating the bareness of what is now revealed, without affect, as the protagonist's former life: 'Yehya Gad el-Rab Saeed spent one hundred and forty nights of his life in the queue' (215).

The novel is set in an indeterminate future. 'The Gate' - which in English translation conveniently echoes the state - came to power 'many years earlier, in the wake of a popular uprising known as the First Storm' (Abdel Aziz 2016: 8). 'Ordinary people' rose up (8) and 
'nearly' toppled the regime, but the movement 'fractured' and 'the situation unraveled' (9). While the people were distracted by internal squabbles, 'the old guard regrouped and began to rebuild. Not long after this, the Gate opened' (9). The serial denomination of the 'first' uprising connotes a dialectic of suppression and revolt, 'tumultuous times' that extend to the recent 'Disgraceful Events' (7) and may include continuing revolt in the present. There is, however, little by way of a tangible frame of reference to confirm any of this as material history. Both publicly and through more insidious practices such as colonising the mobile phone network, the Gate disseminates a hegemonic historiography. Eventually even Amani, who has singlemindedly pursued justice for Yehya, internalises the official story:

They had told her, before she was moved to the great nothingness, that nothing had happened, no injuries, no bullets, no files, nothing ... but Amani hadn't believed it. Even so, perhaps their claims were true. She considered this as she listened to the Gate's breaking message, broadcast on the Youth Station, that a big-budget blockbuster had been filmed in the square recently [... A] few citizens had believed that there were bullets, tear gas, and smoke, even though there clearly hadn't been anything like that, nothing but standard special effects. The Gate called on everyone to remain calm, and avoid being misled by rumors that had been invented and spread by deranged lunatics. It explained that life was to go on as usual. (210, my emphasis $)^{4}$

Given the narrative world's generalized substitution of signifier for meaning, it is feasible that the official story is, in a way, 'true': it may be that a simulation of revolution, and its repression, has been deployed by the Gate to enhance the self-discipline of the populace. 
The Gate claims a didactic monopoly on time itself. The fact that life is expected to 'go on as usual' pinpoints the structural paradox of the world these characters inhabit (Abdel Aziz 2016: 210). The 'fraught palimpsest' that Norbert Bugeja uses to evoke a repeated dashing of collective Arab aspirations (2015: 7) becomes, in this novel, a voiding of temporal frames: there is no going on, only (non-)life 'as usual'. This is, in fact, one of the meanings of achrony: without (chronological) change or difference-creating progression. In The Queue, foreclosure of the possibility of contesting narration is linked to this joint-less, paralysed time. After her indoctrination,

Amani relaxed. She found what she'd long hoped for in the Gate's message - stability and tranquility - while Yehya kept slowly bleeding. It was all a simple fiction, she decided; that was the rational and convincing explanation, but it had fooled her and everyone else. If only she'd accepted it from the start [...]. (210)

Egypt manifests as a basic yet incontrovertible dystopian fiction, in which, it seems, dissent cannot be sustained, or converted into projects.

However, I use the phrase 'tensile present' not only to capture the regulative malleability of 'as usual' iterations of (non-)time, but also to consider whether a tense present can be put to dissident work. The Queue does contemplate anarchic possibilities 'which [would] not so much involve a seizure and destruction of the [state] as the exploration of zones and enclaves beyond its reach' and would, hence, 'valorize a life in the present and in the everyday' (Jameson 2007: 213). The Gate's simulation of the present re-enfolds the past, rescripting history in a way that deters future rebellion. The population managed through this manipulation of time is drawn to 
an imminent breaking point. But as such, at a minimum, every day signifies as a 'robbed time' of survival. Tension implies both an accommodation of strain and something held in reserve.

The queue, as central motif, critically intensifies the present. Despite its linearity and near stasis - occasionally 'some inexperienced soul' gives up and leaves (Abdel Aziz 2016: 10) - the queue unites a heterogeneous ensemble of Egyptians who manifest an enduring 'mode of survival': Bugeja's gloss on al-hayat al-mahsusa. This suggests potential 'political tissue' (2015: 13). The queue develops its own 'conventions' (Abdel Aziz 2016: 29) that hold one's position in the line, even in absentia. Within this framework, characters impose their own rhythms. Um Mabrouk (mother of Mabrouk, 'good fortune') 'gradually moved up the queue' by providing services such as laundry and childcare (71). She gathers rumours and disseminates news. The queue generates conviviality, ideological debate, arguments (for example over the length of the line), and creative entrepreneurship. Denizens exchange seemingly 'trifling concerns and endless stories' that include incipient critiques of the system (29). One elderly woman from the south, for example, complains about the differential allocation of basic resources, such as bread, on the grounds of political loyalty. While trust is difficult under the circumstances, scenes in the queue, and surrounding streets, suggest an incomplete process of containment. Downtown Cairo is 'overflowing' and its days remain 'eventful' $(37,28)$.

The novel's narrative structure, shared between seemingly major and minor character perspectives, enhances this resistant impression of life, diversity, and endurance, described in the novel as a 'visceral tension' (Abdel Aziz 2016: 122). Um Mabrouk reflects that:

the people in the queue lived their lives and solved their own problems without help from anyone. This was exactly what made people outside the queue fear and envy 
them, and what set their schemes in motion. They didn't want the people in the queue to be a united collective or 'one hand'. (71)

On the one hand, the queue literalises the real, or life, as 'a matter of collective spirit: the synchronous, horizontal, or lateral' (Rooney 2015: 45). Despite its linear structure and functional futility, it recalls the midān (Tahrir square), in which collective demands were articulated for al-khubz (bread), al-ḥurriyyah (freedom), and al-karāmah al-i’jtimā'iyyah (social dignity), and popular culture emerged as 'the living countertext of our times' (39). On the other hand, Abdel Aziz's queue resists elision with the midān as 'political-affective nexus' (Bugeja 2015: 3). In the novel, a newly unfolding series of oppositional 'Events' is experienced by those who queue as an inconvenient disruption of their tactical modes of survival. Those whom Um Mabrouk names 'the riffraff' physically break the line, cutting part of the queue off from the other (Abdel Aziz 2016: 89). Political struggle in a conventionally revolutionary sense - aimed at the overthrow of the Gate/state - manifests as another other to Abdel Aziz's characters.

In the aftermath of an ostensibly failed revolution, it is understandable that the author presents ordinary Egyptians as resistant to political interventions that 'couldn't offer any convincing alternatives' to the status quo (Abdel Aziz 2016: 90). However, the reader is presented with the possibility that the rhythm of the people cannot but syncopate - in a non-interventionist counter-time - to an official delineation of public time and space. Um Mabrouk may be wrong in her thesis about the state's reactivity; it is just as likely that the survival processes of the people are selectively tolerated when expedient. Yehya's friend Nagy, observing a tenacious 'beggar lady', surmises that life can only signify in Gate-beneficial ways: 
She'd sat cross-legged in her usual place, not moving an inch, not trying to hide, a helmet on her head, a gas mask hung around her neck, while everyone else was running all around her. She'd reached the pinnacle of valor, her hand always extended in front of her, clearly signaling she was begging for change. After all, one must not stop working, no matter what the circumstances were. Yes, he thought, clearly she'd realized that the economy was lifeblood itself! That the wheel of production and construction must not stop spinning, not even for a moment, not even in the darkest of times. (108)

Alison Rice argues that Djebar's écriture à contretemps, with which I opened this article, 'disrupts the normal course of things, denouncing wrongs past and present in unexpected manners that make it clear that no History is yet established, that History is an ongoing process of dialogue and discussion' (2006: 164). By contrast, we might view the queue, and the novel to which it gives its name, as structurally non-progressive. Abdel Aziz elaborates, in narrative form, what cannot be endured beyond a certain point: life 'as usual' in a history that cannot be seized by the people. There are intimations, off-stage, of repeated disruption to the system, but the relevance of political dissent to interminably waiting Egyptians is not yet - or is no longer - apparent. The Queue's exposure of authoritative 'auto-performativity’ (Rooney 2015: 45) the official production of revolution as containable simulacra and commodity for consumption (including by outsiders) - suggests the apogee of postmodern style, in which 'representation is not conceived as a dilemma but an impossibility, and what can be termed a kind of cynical reason in the realm of art displaces it by way of a multiplicity of images, none of which corresponds to "truth"” (Jameson 2007: 212). 
Such seemingly intractable challenges notwithstanding, Abdel Aziz's novel remains committed to the possibility of dissident representation. 'Tarek' signifies the one who knocks on a door - or a gate - and is asked to reveal his/her identity. ${ }^{5}$ The Queue's final sentences have Tarek adding something to Yehya's file: 'quickly, he added a sentence by hand to the bottom of the fifth document. He closed the file, left it on his desk, and rose' (Abdel Aziz 2016: 215, my emphasis). This supplementation - a sign of subjective change expressed through embodied engagement with another's life - suggests the continued possibility of an uprising; Tarek 'shows his hand', reveals his identity, or (re)inscribes his life, in the service of solidarity. Tarek's name has by this point moved to the inside of the file, meaning that he is now under investigation by the Gate. His 'coming out' as the one who knocks at - asks questions of - the Gate places him in mortal danger. Within the compass of this novel's world, his testimony will probably be erased. His opaque and tenuous intervention resonates, nevertheless, beyond the end of the narrative, signalling something - the dissident expression of a shared life - to the reader.

'The Jazz of an Unknown Future': Omar Robert Hamilton's The City Always Wins (2017)

Omar Robert Hamilton's The City Always Wins, another (Anglo-)Egyptian debut, has been fittingly described as 'a chronological interruption of a novel'. The political stakes of its achrony are foregrounded in the same review, entitled 'pulsing instantiations of a revolution' (Farid 2017: n. p.). Hamilton's novel does more than 'capture' a historical moment: it attempts to materialise the abstract principle of 'revolution' through rhythm and form.

Although fictional, The City Always Wins draws on its author's experience of the 2011 and 2013 Egyptian uprisings. Hamilton is also a filmmaker, activist, and co-founder of Mosireen 
('we are determined', a near-homonym for masriyeen, Egyptians). Between 2011 and 2014, Mosireen was a 'revolutionary activist hub' in downtown Cairo, 'dedicated to supporting and producing citizen media' ('About Mosireen'). At its height, its Youtube channel was the most watched non-profit channel in the world. ${ }^{6}$ Hamilton's novel follows a group of local, diaspora Arab, and foreign activists who, from a flat near Tahrir Square, run the 'Chaos' media collective: an independent, interstitial resistance 'network [...] of trust and consolation and revolution' (Hamilton 2017: 35). Palestinian-American narrator Khalil describes 'an army of infinite mobility' (20) that experientially, linguistically (in Arabic and English), and ideologically connects Egypt with the rest of the region and wider world.

This reflects a perhaps optimistic proposal made by poet Tamim al-Barghouti, that, in the aftermath of the Arab uprisings that gained momentum from late 2010,

narratives are replacing structures, networks are replacing hierarchical pyramids, conviction is replacing obedience, improvisation from the peripheries is replacing central planning, and ideas, for better or for worse, are replacing leaders. (2015: 82)

Arab uprisings certainly divested from hegemonic nationalism, exposing authoritarian states as 'cracked cauldrons' (Barghouti 2015). But it is striking that Khalil's partner Mariam testifies to an almost identical experience, under the Hosni Mubarak regime, to that experienced by Amani in The Queue's hyperbolic future-present:

deep inside the fluorescence of a government building - it must have been the Mogamma3 [a bureaucratic complex to the south of Tahrir] - standing in the eternal queue, she broke down in tears. Mariam remembers it perfectly. The cruelty of it. The 
bureaucratic disdain for our precious breaths. (60)

Khalil reflects similarly on the post-revolutionary dispensation under Abdel Fattah el-Sisi: a 'shadow network of prisons and dungeons and police barracks connected through the constant invisible motion of opaque vehicles and watchful patriots and radio waves' (267). The Gate/state is everywhere, in all times. And yet, as Barghouti's and Hamilton's transnational activist and creative practices typify, emergent 'narratives' and 'networks' continue defiantly to project critical and capacious post-national affiliation. This is reflected in the stylistic, generic, and referential promiscuity of The City Always Wins, and prompts its reflexive commentary on nodes and modes of representation.

A striking innovation of this novel is its structure: Part I 'Tomorrow' is set between October 2011 and February 2012; Part II ‘Today’, between November 2012 and August 2013; and Part III 'Yesterday', during the Sisi era that commenced in July 2013. Organisation is chronological, but the values we typically attach to temporal frameworks are defamiliarised. The novel plots regression to the status quo, reminding us of Achcar's diagnosis of 'relapse' in most postuprising Arab states (2016). Its organisation brings to the surface an established structure of feeling in the Egyptian novel, which tracks aspirations repeatedly stymied by the state in socialist, then neo-liberal, but always authoritarian guises. Popular objectives are never, though, terminally quashed. Hamilton has said that he turned to fiction precisely because one cannot locate the 'bookends' - neither the beginning nor the end - of the Egyptian revolution (Ali 2017: n.p.). The fact that in his novel, 'tomorrow' and 'yesterday' (inversely) bookend 'today' reinforces that central ligature as a fraught but unfinished project - a tensile present.

The novel's opening sentence flags up a present that is chronotopically condensed and 
affectively tense: 'October 9, 2011: She stopped counting the dead an hour ago. These corridors are so compressed with bodies and rage and grief that something, surely, is going to explode' (Hamilton 2017: 5). We are in Cairo's Coptic hospital, in which lie 29 Egyptians shot dead for protesting outside the Maspero state broadcasting building. The January/February uprising is relayed through memory perhaps in part because, as one character suggests, it is 'impossible to do the Eighteen Days [that led to the ousting of Hosni Mubarak] without being clichéd. It's ruined already by its overtelling' (149). ${ }^{7}$ The novel's opening scene nevertheless foregrounds activist commitment to a mass popular revolt which encompassed all of Egypt's religious communities. Moreover, it prefigures the trauma that pervades this novel and influences its temporal counter-logic. ${ }^{8}$ The structure of trauma is both anachronistic and achronic - the unpredictable eruption of traumatic memories unsettles our sense of time's linear progression and may block its unfolding altogether.

Citizen-journalists encounter distraught parents intent only on burying their children. Khalil and friends realise that abstract, future-oriented principles cannot compensate for intimate loss: 'There can never be justice', grieves one mother (Hamilton 2017: 7). The novel assiduously crosscuts the narrative with testimonies from the families of the revolution's 'martyrs'. It translates the closely connected concepts of martyrdom and witnessing (shahāda) into a secular register, remaining aware of the ways in which one might selectively apportion grief. The central characters are marked by what they see, do, and do not experience. Khalil is haunted by a female doctor shot by the army, who dies in his arms. Mariam 'smells the morgue everywhere $[\ldots]$ It drips off her hair like cigarette smoke in the shower [...] She dreams $[\ldots]$ like an animal, in dark smells and twitched traumas' (217). The army's massacre of Muslim Brotherhood supporters in 2013 resonates like 'a black hole in the center of our lives. A silence, an unsaid lurking'. Khalil, committed to a secular solution for Egypt, wonders: 'Should we 
have been ready to die for our enemies? Did we do this?' (230-31).

The materiality of death serves as a constant reminder not only of what a teleological imagination would disavow, but also of the structural limitations of the globalised resistance movement. Khalil and friends, representatives of a networked, secular, liberal avant-garde, commit their lives to a revolution they can never entirely represent. Khalil relays the 'potency' of 'slip[ping] into a unitary anonymity' in the uprisings of 2011, in which - recalling Djebar's rebato - Tahrir Square becomes a 'no-man's land' shaped 'by the rhythm of the battle' (Hamilton 2017: 41). But he is increasingly aware of the temptation to "plug into our cyberpsyche of chats and kisses and matching opinions and block and like and report buttons, [thereby] retreating from the world that is cold and hard and dark into our digital city of filtered control and clarity' (41, 238). Khalil's (and, inferentially, Hamilton's) perspective is also explicitly circumscribed by gender: both the resurgent regime and the revolutionary opposition, it is acknowledged, attempt to 'appropriat[e], coloniz[e] Mariam's language, her life' as a woman (141).

The City Always Wins is tonally capacious. Despite its foregrounding of state violence, the initial 'tomorrow' section captures the euphoria of the initial 2011 uprising, ' $[\mathrm{t}] \mathrm{he}$ crucible in which new bonds, a new chemistry, was catalyzed' (Hamilton 2017: 43). Cairo is claimed as a city of 'contrapuntal' flows and interminglings, in which martial management of space can be overwhelmed by the 'riotous and discordant and defiant' rhythms of the street (10). The cover of the UK edition features a foreshortened image of tenement blocks, revealing neither ground nor sky. This suggests both oppression - the city as 'cement supercolony' - and the progressive potential of propinquity, or 'neighborliness on a massive scale' (23). Vertical buildings are transected by black lines, which evoke censorship but are alternated with the words of 
Hamilton's defiantly presentist title. Khalil associates 2011 Cairo with 'the jazz that is beauty in the destruction of the past, the jazz of an unknown future'. The city is cast as an improvisational style in which 'occasionally brilliant solos stand $[\ldots]$ high above the steady rhythm of the street' (10). Khalil later comes to see Cairo, in stark contrast, as 'urban necropolis' (190).

The key question that Hamilton's novel suspends is: 'what comes after saying no?' (Hamilton 2017: 85). Khalil and his friend Hafiz discuss decolonizing and revolutionary precedents, flagging up a generally cyclical process of uprising and repression, but keeping faith with 'the [strong] idea' that cannot be put down by force (86). They are aware that within the compass of Egypt's recent political history, revolution reproduces the status quo, and that even democratic processes are flawed: '[t]he young do all the dying and the old go to the polls to vote for other old fucks to tell the young what to do' (85). The regime's post-2013 'corrective revolution' is, in fact, a worse than generic outcome (194). In the final 'Yesterday' section of the novel, Khalil's anomie tips toward borderline suicidal feelings, as he contemplates 'the long end of the extraordinary' (271). An investment in modernist artistic experimentation gives way to a present conjuncture that is bleakly postmodern: in Sisi's Cairo, Khalil sees 'only nostalgia and kitsch and superheroes and heartbreak and a sealed fate and surrender' (284).

We return to the question of how the afterwardly can be 'productive disjunctive' (Parikka 2018: 41, my emphasis). Fredric Jameson urges us to focus, in our engagements with utopian fiction, on 'the break itself' - Hamilton's 'no' - rather than 'what things would be like after the break' (2007: 232). The limitations of utopia (and dystopia) are both political and formal: an imagined society in which all political differences are resolved, for better or worse, would no longer ‘energize and compel us to action' (xiv). A utopian future would be 'paradoxically also the end 
of time, the end of history' (2007: 7): there would be nothing further to do and still less to narrate. The value of the utopian imagination arguably lies in its structure - the drive to imagine a better world - rather than in specified political objectives beyond those pertaining to bread, dignity, and social justice. As Ziad Elmarsafy has suggested, revolutionary desire - the people want - reveals a 'genealogy' of 'hope' that is also 'a queer series of prediction' (2013: 16). It is no wonder we see an increase in the speculative genre production of 'strange horizons' (Murphy 2017).

The City Always Wins can also be defined as speculative fiction. However, the stress falls less on what happens after the revolution than on the unknown potential - and risk - of a tensile present. Early in the novel, Khalil describes the sun setting behind the still smouldering ruins of Mubarak's National Democratic Party headquarters, 'our antimonument to the future' (Hamilton 2017: 9). The image condenses a not-quite-erased history and an as-yet-undefined future. We are privy to a telling epiphany of Mariam's when confronted with the brutal negligence of the Mubarak regime:

How short life is. Live is to be lived and death is to be feared and hated and remembered and resisted every day. There is only now, there is not even tomorrow. A life that others will talk about when it leaves us. That's the goal. A life that conquers death with memory. (Hamilton 2017: 61)

Khalil also proposes that it is 'the stories they'll tell for years to come' that will endure (45). Although he later seems to qualify this commitment to counter-historiographic testimony even memories, he thinks, slip and fade at the edges (247) - this implies a rationale for turning it into art. The novel in turn, reflexively alludes to the limited appeal of post-Arab uprising 
narratives for readers in English: 'there is no glamour to these long, painful afternoons' of the revolution's aftermath, Khalil thinks: 'No one to watch the withering spectacle' (152). A sense of a loss of vocation, and an increased sense of himself as outsider, lead to Khalil's separation from Mariam and departure from Egypt.

Al-Sisi's speech on 30 June 2013 issued an imperative to Mohammad Morsi's short-lived government that if 'the people's demands' were not met, the military would 'announce a roadmap [...] for the future' (Ali 2017: n.p.). People's demands are patently neither contained nor exhausted by such iterations. This kind of performative co-optation of popular desire in the production of political chronology (which disavows continuity with the past) leads to the stringent challenge issued by Hamilton's novel. The author has said that in writing The City Always Wins, he 'tried to take optimism and hope out of the equation'. The narrative expresses a vital break with an unviable life - 'You do something because you have no other choice' but the desperate, entrenched conditions which produce this break preclude romantic endings (ctd. in Ali 2017: n.p.). This narrative is not, then, driven by 'the realization of a utopian system' (Ali 2017: n.p., my emphasis). While its characters worry that they do not have a 'roadmap', an anarchist scepticism toward teleology is apparent. Khalil reflects that: 'The ballot box exists to quell the revolution [...] We want another way, a way as yet unknown' (Hamilton 2017: 85). We see, here, an afterwardly orientation in which 'the expression of the Utopian impulse [comes] as close to the surface of reality as it can without turning into a conscious Utopian project' (Jameson 2007: 8).

Jameson applauds the revitalisation of utopianism by a 'new generation of the postglobalization Left', exemplified by a transnational collective such as Hamilton's Mosireen, which unites 'First World' activists and the globally disenfranchised, precisely because their 
critique of traditional conceptions of revolution 'clear[s] the discursive field' (2007: xii). Jameson cautions against untimely implementation of a practical-political project, seeing merit in 'meditation on the impossible, on the unrealizable in its own right', on 'a rattling of the bars and on an intense spiritual concentration and preparation for another stage which has not yet arrived' (233). A resilient present should be a 'time open to the future'; it prefigures a 'radical and systemic break' with what is predictable, indeed reiterative (228). It invites extemporisation, creation as if without preparation.

In fact, improvisation tends to redeploy the means at hand: it transforms, adapting, complicating, and extending form, using repeated and echoed phrasing, call and response patterns, and thematic elaborations. Khalil surmises: 'It's what you do with the old - that is what's new' (Hamilton 2017: 100). Achrony and 'robbed time' also define themselves in relation to structures that have become sedimented as normative. This clarifies the afterwardly less as sui generis than as creative, counter-textual provocation - skirmishes in a tensile present that continually reterritorialize the ground, to recall Djebar's use of the rebato, denizen life in the queue, and Hamilton's representation of Tahrir Square. The afterwardly is more than 'progressive' politics in literary guise; it is too sceptical about existing 'road maps'.

It is redundant to ask why literary 'afterwords' on twenty-first century Egyptian uprisings are tonally dark, affectively morbid or depressing, and almost alexithymic. In 2017/18, the Egyptian 'human right's crisis continued unabated', featuring systemic torture, enforced disappearances, extrajudicial executions, arbitrary arrests and detention, grossly unfair trials leading to death sentences, and a crackdown on civil rights NGOs (Amnesty International 2018: 151-52). Egypt's literary writers have a longstanding remit as 'conscience of the nation' in the absence of conscientious political guardians thereof (Jacquemond 2008). This 
article has explored what kinds of response a depressing, or morbid, structure of feeling solicits. It illustrates some of the ways in which dystopian/utopian imagination or creative 'Fancy', as always more than mere 'ornament and spatial decoration [,] sets itself on the move' (Jameson 2007: 229, 230).

The Queue disturbingly mirrors the 'morbid symptoms' of an Egyptian postcolony in which 'the future horizon is apparently closed, while the horizon of the past has apparently receded' (Achcar 2016; Mbembe 2001: 17). The City Always Wins more emphatically says 'no' and resists closure. Khalil does return to continue the struggle. He ends his narration 'primed for another signal, another job, another plan, another way of thinking', even if at present 'there is only darkness' (Hamilton 2017: 307). The title's 'always' thereby re-enfolds the novel's temporal frames, reminding us of an ongoing Egyptian potential for resistance. The final words of Hamilton's novel evoke his friend Rosa's 'prison far out beyond the city limits' (307). However, from her cage in court, Rosa has just delivered a message to Khalil about an impending prison strike. As she is led from court, she 'looks him in the eye', her 'body pulsing confidence'. And Khalil 'feel[s] it again, the current forcing my hands into a fist' (306). Khalil continues to feel - and Hamilton's post-revolutionary narrative persists in expressing - the pulse of a shared, tense life that continues to beat, to count time: a counter-time that is always potentially activated.

\section{References}

Abdel Aziz, Basma (2017), interviewed by Elisabeth Jaquette, 'The Waking Nightmare: PostRevolutionary Egyptian Dystopias', 16 July 2017, British Library, London.

Abdel Aziz, Basma (2016), The Queue, trans. Elisabeth Jaquette, London: Melville House. 'About Mosireen', http://mosireen.org/?page_id=6 Achcar, Gilbert (2016), Morbid Symptoms: Relapse in the Arab Uprising, London: Saqi. Ali, Rozina (2017) 'What a Novel Can Say About the Egyptian Revolution', The New Yorker, 1 August, n. p. 
Al-Barghouti, Tamim (2015), 'Cracked Cauldrons: The Failure of States and the Rise of New Narratives in the Middle East', in Raja Shehadeh and Penny Johnson (eds), Shifting Sands: The Unravelling of the Old Order in the Middle East, London: Profile, 82-97.

(2018), Amnesty International Report 2017/18: The State of the World's Human Rights, London: Amnesty International Ltd.

Blasim, Hassan (ed) (2016), Iraq+100, Manchester: Comma Press.

Brand, Laurie A. (2014), Official Stories: Politics and National Narratives in Egypt and Algeria, Stanford, CA: Stanford University Press.

Brooks, Peter (1984), Reading for the Plot: Design and Intention in Narrative, Cambridge, MA: Harvard University Press.

Bugeja, Norbert (2015), 'Guest Editor's Introduction: Postcolonial Springs? 2011 and the Articulation of Post-Despotic Culture in the Southeastern Mediterranean', CounterText 1: $1,1-19$.

Callus, Ivan, and James Corby (2015), 'Countertextuality and the Political', CounterText 1: 1, $\mathrm{V}-\mathrm{x}$.

Cohn, Jesse (2016), 'Under History's Changing Climate: Anarchism's Romantic Moods', Literature Compass 13: 1, 13-23.

Dawood, N. J. (1990), The Koran, with Parallel Arabic Text, trans. N. J. Dawood, 5th rev. ed., London: Penguin.

Djebar, Assia (1995), L'Amour, la fantasia, Paris: Albin Michel.

Djebar, Assia (1985), Fantasia: An Algerian Cavalcade, trans. Dorothy S. Blair, London: Quartet.

Elsadda, Hoda (2012), Gender, Nation, and the Arabic Novel: Egypt, 1982-2008, New York: Syracuse University Press.

Eltoukhy, Nael (2014), Women of Karantina [Nisa' al-Karantina, 2013], trans. Robin Moger, Cairo: American University in Cairo Press.

Erickson, John (2009), Islam and Postcolonial Narrative, Cambridge: Cambridge University Press.

Farid, Farid (2017), 'Pulsing Instantiations of a Revolution: "The City Always Wins" by Omar Robert Hamilton', Los Angeles Review of Books, 25 August, https://lareviewofbooks.org/article/pulsing-instantiations-of-a-revolution-the-cityalways-wins-by-omar-robert-hamilton/\#!, n. p.

Hafez, Sabry (2010), 'The New Egyptian Novel: Urban Transformation and Narrative Form', New Left Review 64, n. p.

Hamilton, Omar Robert (2017), The City Always Wins, London: Faber \& Faber.

Jacquemond, Richard (2008), Conscience of the Nation: Writers, State, and Society in Modern Egypt, trans. David Tresilian [2003], Cairo: American University in Cairo Press.

Jameson, Fredric (2007) Archaeologies of the Future: The Desire Called Utopia and Other Science Fictions, London: Verso.

Lynx Qualey, Marcia (2017), 'Basma Abdel Aziz on Writing “The Queue”, Arabic Literature (in English), 31 August, https://arablit.org/2017/08/31/basma-abdel-aziz-on-writingthe-queue/.

Mahfouz, Naguib (2001), The Cairo Trilogy [Al-Thulathiyya, 1956-57], trans. William Maynard Hutchins, Olive E. Kenny, Lorne M. Kenny, and Angele Botros Samaan, New York: Albert A. Knopf.

Mbembe, Achille (2001), On the Postcolony, Oakland, CA: University of California Press. Mehrez, Samia (2010), Egypt's Culture Wars: Politics and Practice, London: Routledge.

Moore, Lindsey (2018), Narrating Postcolonial Arab Nations: Egypt, Algeria, Lebanon, Palestine, New York: Routledge. 
Murphy, Sinéad (2017), 'Science Fiction and the Arab Spring: the critical dystopia in contemporary Egyptian fiction', Strange Horizons, 30 October, $\mathrm{http}$ ///strangehorizons.com/non-fiction/science-fiction-and-the-arab-spring-thecritical-dystopia-in-contemporary-egyptian-fiction/.

Parikka, Jussi (2018), 'Middle East and Other Futurisms: Imaginary Temporalities in Contemporary Art and Visual Culture', Culture, Theory and Critique 59: 1, 40-58.

Rabie, Mohammad (2016), Otared ['Utarid, 2014], trans. Robin Moger, Cairo: Hoopoe Fiction.

Rice, Alison (2006), Time Signatures: Contextualizing Contemporary Francophone Autobiographical Writing from the Maghreb, Lanham, MD: Lexington.

Rooney, Caroline (2011), 'Introduction', in Caroline Rooney and Ayman El-Desouky (eds), Egyptian Literary Culture and Egyptian Modernity, Special Issue, Journal of Postcolonial Writing 47: 4, 369-376.

Rooney, Caroline (2015), 'Sufi Springs: Air on an Oud String', CounterText 1: 1, 38 —58.

Saadawi, Ahmed (2018), Frankenstein in Baghdad [Frankenstein fi Baghdad, 2013], trans. Jonathan Wright, London: Oneworld.

Sharma, Sarah (2014), In the Meantime: Temporality and Cultural Politics, Durham, NC: Duke University Press.

Soueif, Ahdaf (2014), Cairo: My City, Our Revolution, London: Bloomsbury.

Towfik, Ahmed Khaled (2011), Utopia [2008], trans. Chip Rossetti, Doha: Bloomsbury Qatar Foundation.

West-Pavlov, Russell, Temporalities, Abingdon: Routledge, 2013.

\footnotetext{
${ }^{1}$ My re-translation. Cf. 'In time to the rhythm of the rebato, I am alternately the besieged foreigner and the native swaggering off to die' (Djebar 1985: 215).

${ }^{2}$ Towfik, although a prolific Egyptian author of genre fiction, was first translated into English in the context of the 2011 uprisings: an indication of the ways in which Arab elaborations of dysfunctional society have become internationally marketable in the context of the 'Arab Spring' and its aftermath. Contemporary Iraqi writers are also relatively visible producers of literature in dystopic registers: Hassan Blasim has had considerable international exposure as a short story writer and as editor of Iraq+100 (2016), and the English translation of Ahmed Saadawi's IPAF (International Prize in Arabic Fiction) winner Frankenstein in Baghdad (2018; Frankenstein fi Baghdad, 2013) was much anticipated. Richard Jacquemond suggests that "vast sections of the [Egyptian] book market consist of "minor genres", (including translations into Arabic). However, Arab literary criticism has paid little attention to these. Jacquemond approaches them - in a book originally published in 2003 - as "paraliterature' that negatively defines the borders of the legitimate literary field (2008: 156-157). ${ }^{3}$ As I write this article, BBC Newsnight is screening a report entitled 'Crushing Dissent in [al-Sisi's] Egypt', 22 February 2018, http://www.bbc.co.uk/programmes/p05z0dv2 ${ }^{4}$ In July 2017, the Egyptian Minister of Education announced that it would strike references to the 2011 and 2013 uprisings from upcoming examinations (Ali 2017: n. p.).

${ }^{5}$ In Surah 86 ('The Nightly Visitant') of the Qu'ran, the 'nightly visitant' or night-comer (atTariq) is 'the star of piercing brightness', which represents consciousness of the sacredness of life. The surah continues: 'For every soul there is a guardian watching it. Let man reflect from what he is created' (Dawood 1990: 590).

${ }^{6}$ See mosireen.org. The collective launched a major video archive in January 2018.

${ }^{7}$ This contrasts with Hamilton's mother's Cairo: My City, Our Revolution (2014).
} 
${ }^{8}$ Hamilton's interest in trauma is similarly evident in his short Palestinian film Though I Know the River is Dry/Ma'a Anni A 'rif Anna Al-Nahr Qad Jaf (2013). 